\title{
Bacterioplankton abundance, biomass and production in a Brazilian coastal lagoon and in two German lakes
}

\author{
ANDRÉ L. S. FURTADO ${ }^{1}$, PETER CASPER ${ }^{2}$ and FRANCISCO A. ESTEVES ${ }^{1}$ \\ ${ }^{1}$ Laboratório de Limnologia, Departamento de Ecologia, I.B., Universidade Federal do Rio de Janeiro, \\ Cidade Universitária, Ilha do Fundão, 21941-590 Rio de Janeiro, Brazil \\ ${ }^{2}$ Institut für Gewässerökologie und Binnenfischerei, Alte Fischerhütte 2 \\ D-16775 Stechlin-Neuglobsow, Germany \\ Manuscript received on November 10, 1999; accepted for publication on October 20, 2000; \\ presented by Wolfgang C. Pfeiffer
}

\begin{abstract}
The bacterioplanktonic abundance, biomass, and production within a tropical lagoon (Cabiúnas, Brazil) and two temperate lakes (Stechlin and Dagow, Germany) were compared. Bacterial abundance and production were significantly different among the three water bodies. The lowest bacterial production $\left(0.8 \mu \mathrm{g} \mathrm{Cl}^{-1} \mathrm{~d}^{-1}\right)$ was observed in the tropical Cabiúnas Lagoon despite its higher mean temperature and dissolved organic carbon concentration. Highest bacterioplankton abundance $\left(2.6 \times 10^{9}\right.$ cells $\left.^{-1}\right)$ and production $(68.5 \mu \mathrm{g}$ $\mathrm{C}^{-1} \mathrm{~d}^{-1}$ ) were measured in eutrophic Lake Dagow. In oligotrophic Lake Stechlin, the lowest bacterial biomass $\left(48.05 \mu \mathrm{g} \mathrm{C}^{-1}\right)$ was observed because of lower bacterial biovolume $\left(0.248 \mu \mathrm{m}^{3}\right)$ and lower bacterial abundance. Bacterial populations in the temperate lakes show higher activity (production/biomass ratio) than in the tropical lagoon. The meaning of isotopic dilution and leucine incorporation by non-bacterial micro-organisms were evaluated in the oligotrophic temperate system. Leucine uptake by non-bacterial micro-organisms did not have significant influence on bacterial production.
\end{abstract}

Key words: bacterial production, leucine incorporation, tropical lagoon, temperate lake.

\section{INTRODUCTION}

Tropical aquatic environments are very different from temperate environments, influencing the type of organisms and their metabolic processes in these different environments. For instance, tropical freshwater communities are mainly regulated by variations in the hydrological conditions rather than by temperature (Junk \& Furch 1993, Anésio et al. 1997, Gomes \& Agostinho 1997). As the temperature varies seasonally in temperate regions, primary and secondary production reaches a maximum during the warm months (Lampert \& Sommer 1993).

Correspondence to: André Luiz dos Santos Furtado

E-mail: furtado@biologia.ufrj.br
Furthermore, Hecky et al. (1993) suggested that particulate matter in temperate freshwater ecosystems frequently exhibits low $\mathrm{P}$ concentration, while in tropical aquatic systems either $\mathrm{N}$ or $\mathrm{P}$ may be limiting or even non-limiting. Many tropical water bodies are warm and shallow, and thus remain polymictic. These latter water bodies often have large littoral zones colonized by macrophytes. In these water ecosystems, eutrophication enhances the growth of macrophytes in contrast to the over-growth of phytoplankton in temperate waters (Oskam \& van Genderen 1996), where the principal source of DOM and POM comes from phytoplankton or allochthonic inputs. 
Bacterial abundance, chlorophyll $a$ (which reflects the trophic state) and temperature have been described as the most important factors influencing bacterial production in marine and freshwater aquatic habitats (White et al. 1991). But in tropical ecosystems, since the temperature is relatively constant, it may be conjectured that the natural dynamics of bacterial production and density is controlled by others factors such as nutrient availability or interaction between micro-organisms.

The principal objective of this study was directly to compare the influence of temperature and trophic state on abundance, biomass and production of heterotrophic bacteria in the water column and their spatial variability within a tropical lagoon and two temperate lakes. The tropical Cabiúnas Lagoon (Brazil) and the temperate Lakes Stechlin (oligotrophic) and Dagow (eutrophic), both in Germany, were used for comparison. Pronounced differences in temperature, trophic state, and morphological characteristics were observed in these environments and described in this study.

In addition, earlier research describing problems using labeled markers (as isotopic dilution; Kirchman 1993) and uptake by micro-organisms other than bacteria (van Looij \& Riemann 1993, Kamjunke \& Jähnichen 2000), were proofed with samples from Lake Stechlin in this report.

\section{MATERIAL AND METHODS}

Located on the coastal zone of Rio de Janeiro State (Brazil), Cabiúnas Lagoon was formed during the last Holocene transgression that occurred in the Pleistocene (Perrin 1984). It is separated from the Atlantic Ocean by a $100 \mathrm{~m}$ sand bar. Its water is colored by humic substances and has an average salinity of about 0.3 . The littoral zone is principally colonized by the macrophytes Typha domingensis and Potamogeton stenostachys. The climate is tropical wet and the long-term average minimum temperature is $18.7^{\circ} \mathrm{C}$.

The lagoon is situated in a sand-dune habitat (Restinga) and surrounded by dense vegetation formed mainly by representatives of the Theopharastaceae, Anarcadiaceae, Myrtaceae, Clusiaceae, Ericaceae, Melastomataceae and Bignoniaceae (Araújo \& Henriques 1984). Panosso et al. (1998) described the morphology in detail and Petrucio (1998) reported the limnological characteristics. The oligotrophic Lake Stechlin and the eutrophic Lake Dagow are both situated in the Baltic Lake district in Northeast Germany. Both lakes are of glacial origin and the shores are forested mainly by Pinus sylvestris and Fagus sylvatica. Both lakes were described by Casper (1985). In contrast to Cabiúnas Lagoon, the lakes present typical stratification during summer. Some morphological and limnological characteristics of all three sampling sites are summarized in Table I.

Water samples were collected in Lakes Stechlin and Dagow in February 1998 and in Cabiúnas Lagoon in September 1998. Samples were taken in each aquatic environment at three stations along a transect. In all cases, station L1 was located in a littoral zone without macrophytes, station L2 in a littoral zone colonized by macrophytes, and station $\mathrm{P}$ in the pelagic zone. At the pelagic zone, samples were collected at three depths: near the water surface $(\mathrm{Pa})$, at half water depth $(\mathrm{Pb})$ and near the bottom (Pc). In Cabiúnas Lagoon, the near bottom samples were taken at $3.5 \mathrm{~m}$. In Lakes Stechlin and Dagow the near bottom subsamples were taken at $30 \mathrm{~m}$ and $9 \mathrm{~m}$, respectively.

In the German lakes, temperature and oxygen profiles were measured using a Microprocessor Oximeter Oxi 196 (WTW, Germany) and N and P-concentrations by a FIA-5010 Analyser (Tecator, Sweden). In the Brazilian lagoon, temperature was measured using a Cole Parmer thermistor Model 8402-10 and oxygen concentration by the Winkler method. $\mathrm{N}$ and $\mathrm{P}$ analysis were done using the Kjeldahl method (Golterman et al. 1978). Dissolved organic and inorganic carbon concentrations were determined for all sites using a TOC-5050 Analyser (Shimadzu, Japan).

Bacterial abundances were determined after fixing with formalin $(4 \% \mathrm{v} / \mathrm{v})$. Subsamples $(\mathrm{n}=3)$ 


\section{TABLE I}

Morphological and limnological characteristics of Cabiúnas Lagoon, Lake Stechlin and Lake Dagow.

\begin{tabular}{|c|c|c|c|c|c|c|c|c|c|}
\hline & $\begin{array}{l}\text { area } \\
\mathrm{km}^{2}\end{array}$ & \multicolumn{2}{|c|}{$\begin{array}{l}\text { depth } \\
\text { meter }\end{array}$} & \multicolumn{2}{|c|}{$\begin{array}{c}\text { water } \\
\text { temperature }{ }^{\circ} \mathrm{C}\end{array}$} & \multicolumn{2}{|c|}{$\mathrm{pH}$} & \multicolumn{2}{|c|}{$\begin{array}{l}\text { conductivity } \\
\qquad \mu \mathrm{S} \mathrm{cm}^{-1}\end{array}$} \\
\hline & & $\max$. & mean & $\min$. & $\max$ & $\min$. & $\max$ & $\min$. & $\max$ \\
\hline Cabiúnas Lagoon & $0.34^{1}$ & 4.0 & $2.4^{1}$ & 21.0 & $28.5^{3}$ & 6.0 & $7.4^{3}$ & 300 & 14.300 \\
\hline L. Stechlin & $4.3^{2}$ & 68.0 & $22.8^{2}$ & 3.7 & $19.9^{5}$ & 7.5 & $8.6^{5}$ & 246 & $336^{5}$ \\
\hline \multirow[t]{3}{*}{ L. Dagow } & $0.3^{2}$ & 9.5 & $4.9^{2}$ & 1.7 & $21.5^{6}$ & 7.1 & $9.1^{6}$ & 360 & $500^{6}$ \\
\hline & $\begin{array}{l}\text { volume } \\
\times 10^{6} \mathrm{~m}^{3}\end{array}$ & \multicolumn{2}{|c|}{$\begin{array}{c}\text { transparency } \\
\text { Secchi disk } \\
\text { meter }\end{array}$} & \multicolumn{2}{|c|}{$\begin{array}{c}\text { oxygen } \\
\text { concentration } \\
\mathrm{mg} \mathrm{l}^{-1}\end{array}$} & \multicolumn{2}{|c|}{$\begin{array}{l}\text { N-total } \\
\mathrm{mg} \mathrm{l}^{-1}\end{array}$} & \multicolumn{2}{|c|}{$\begin{array}{l}\text { P-total } \\
\mu \mathrm{g} \mathrm{l}^{-1}\end{array}$} \\
\hline & & $\min$. & $\max$ & $\min$. & $\max$ & $\min$. & $\max$ & $\min$. & $\max$ \\
\hline Cabiúnas Lagoon & $1.4^{1}$ & 0.8 & $2.8^{3}$ & 2.6 & $7.7^{4}$ & 0.27 & $1.07^{4}$ & 4.4 & $24.0^{4}$ \\
\hline L. Stechlin & $96.9^{2}$ & 7.2 & $12.3^{5}$ & 5.3 & $12.5^{5}$ & 0.34 & $1.2^{5}$ & 6.0 & $15.0^{5}$ \\
\hline L. Dagow & $1.2^{2}$ & 1.8 & $3.2^{6}$ & 0.0 & $11.8^{6}$ & 0.77 & $2.37^{6}$ & 23.0 & $199.0^{6}$ \\
\hline
\end{tabular}

${ }^{1}$ Panosso et al. (1998). ${ }^{2}$ Casper (1985). ${ }^{3}$ data from 1993 to 1995, Petrucio (1998). ${ }^{4}$ data from 1993 to 1995, Marinho (pers. comm.). ${ }^{5}$ data from 1998 from 0-10 m, Koschel (pers. comm.). ${ }^{6}$ data from 1996 from 0-8 m, Koschel (pers. comm.).

were stained with the fluorochrome 4',6-diamidino2-phenylindole (DAPI, $5 \mathrm{mg} \mathrm{l}^{-1}$ ) for 10 minutes in the dark and filtered onto black polycarbonate membrane filters $(0.2 \mu \mathrm{m}$; Nuclepore Corp.) under low vacuum pressure $<30 \mathrm{~mm} \mathrm{Hg}$ (Kepner \& Pratt 1994). Bacterial cells were counted using a fluorescence microscope (Leica DMBR, HBO $50 \mathrm{~W}$, BP 355-425, RKP 455 and LP 470) with a magnification of $2000 \times$ under immersion. Ten randomly selected microscopic fields or a minimum of 200 bacteria per filter were counted.

The bacterioplankton production (BP) was measured according to Smith and Azam (1992). Samples $(n=5)$ were incubated for 1 hour in the dark with $\mathrm{L}-\left[4,5-{ }^{3} \mathrm{H}\right]$ leucine (specific activity $136 \mathrm{Ci} \mathrm{mmol}^{-1}$, $50 \mathrm{nM}$ final concentration). Formalin ( $4 \% \mathrm{v} / \mathrm{v})$ was added to controls prior to the isotope addition and to the samples directly after incubation to terminate reactions. Samples were shaken and then centrifuged at $14,000 \times \mathrm{g}$ for 10 minutes. The supernatant was aspirated and the remaining pellet was resuspended and washed with 5\% TCA and $80 \%$ ethanol. To evaluate the saturation level of leucine uptake, samples from Lake Stechlin were incubated as described with 20, 50, 100, 150 and $200 \mathrm{nM}^{3} \mathrm{H}$-leucine. In all experiments, labeled leucine was diluted three times with nonlabeled leucine. The samples were counted in a Packard 1600 TR liquid scintillation counter after adding a liquid scintillation cocktail (Ultima Gold, Packard Co.). The BP was calculated according to Simon and Azam (1989):

$$
\begin{aligned}
& \mathrm{BP}(\mathrm{g})=(\text { mol leucine incorporated }) \times(0.073) \\
& \times(131.2) \times(0.86) \times(\text { isotopic dilution })
\end{aligned}
$$

where 0.073 is the leucine/protein ratio, 131.2 is the molecular weight of leucine and 0.86 is the ratio of cellular carbon to protein. The isotope dilution was considered as 2.

To assess the effect of non-bacterial micro-organisms on the bacterial production, unfiltered and filtered water samples from Lake Stechlin (polycarbonate filters, $0.8 \mu \mathrm{m}$, Nuclepore Corp.) were incubated with leucine as described earlier.

To determine bacterial size, microphotographs (Kodak Elite II 100) of DAPI stained samples were 
projected onto a screen, and a total of 50 bacteria were randomly measured per sample.

Bacterial biovolume was calculated from sized bacteria (Bratbak 1985):

$$
\text { Bacterial biovolume }=(\pi / 4) \times \mathrm{W}^{2} \times(\mathrm{L}-\mathrm{W} / 3)
$$

where $\mathrm{L}$ is length and $\mathrm{W}$ is width of the cells, applying this formula to $\operatorname{cocci}(\mathrm{L}=\mathrm{W})$.

Carbon content was estimated using the factor $105 \mathrm{fg} \mathrm{C} \mu \mathrm{m}^{-3}$ (Theil-Nielsen \& Søndergaard 1998).

\section{RESULTS AND DISCUSSION}

Some limnological parameters measured in the three water bodies at the time of sampling are summarized in Table II. Temperature and dissolved organic carbon were higher in Cabiúnas Lagoon, in contrast to both German lakes. The lagoon is a typical coastal tropical lagoon that does not stratify and remains warm during the austral winter. Both German lakes were sampled at the end of winter. Each had turned over and exhibited higher concentrations of inorganic carbon than the lagoon. Oxygen was found to be saturated in all lakes; and nutrient concentrations were similar at all sites. The $\mathrm{P}-$ and $\mathrm{N}$ concentrations indicate the humic Cabiúnas Lagoon as an oligotrophic system.

The highest bacterial abundance (BA) was estimated in the eutrophic Lake Dagow, which varied from $1.6 \times 10^{9}$ to $2.6 \times 10^{9}$ cells $^{-1}$ (Fig. 1C) In Cabiúnas Lagoon, bacterial abundance (BA) was lower than in Lake Dagow. BA varied from $1.0 \times 10^{9}$ to $1.5 \times 10^{9}$ cells $1^{-1}$ (Fig. 1A) which is in the range of the most oligotrophic lakes (Chrzanowski et al. 1996, Lindell \& Edling 1996, Reche et al. 1997). The lowest BA of the three systems examined was observed in the oligotrophic Lake Stechlin

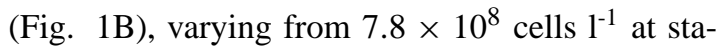

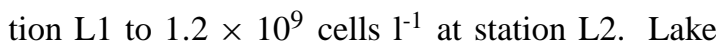
Stechlin was the only site where the bacterial abundance was significantly different among the stations (Kruskal-Wallis, $\mathrm{p}<0.05$ ).

Bacterial production (BP) measured in the different systems ranged from 0.8 to $68.5 \mu \mathrm{g} \mathrm{C}^{-1} \mathrm{~d}^{-1}$.
The lowest bacterial production was detected in stations of Cabiúnas Lagoon ( 0.8 to $4.3 \mu \mathrm{g} \mathrm{Cl}^{-1} \mathrm{~d}^{-1}$, Fig. 1A) and Lake Stechlin (3.6 to $6.4 \mu \mathrm{g} \mathrm{C}^{-1} \mathrm{~d}^{-1}$ ). The highest BP was calculated for the littoral zone colonized by macrophytes (L2) in Lake Dagow (68.5 $\mu \mathrm{g}$ $\left.\mathrm{C}^{-1} \mathrm{~d}^{-1}\right)$.

Bacterial production was not significantly different among the stations (L1, P and L2) for all studied ecosystems (Kruskal-Wallis, $\mathrm{p}<0.05$ ), but comparing the three water bodies, both BA and BP were significantly different (Kruskal-Wallis, p < 0.05).

Values of BP measured in February in the temperate lakes were higher than those previously measured by Babenzien and Babenzien (1985) based on ${ }^{14} \mathrm{C}$-glucose uptake. In this study bacterial production in Lake Stechlin ranged from 0.024 to $1.4 \mu \mathrm{g} \mathrm{C}$ $\mathrm{l}^{-1} \mathrm{~d}^{-1}$ and in Lake Dagow 0.24 to $13.2 \mu \mathrm{g} \mathrm{C}^{-1} \mathrm{~d}^{-1}$ over the course of a year.

Even though Cabiúnas Lagoon exhibited higher mean temperature and DOC (Table II), the lowest bacterial carbon production was measured in this lagoon. Bacterial production observed in this lagoon was comparable to those of temperate lakes during autumn (Tulonen 1993) and lower than observed in other brazilian aquatic ecosystems such as the Patos Lagoon (Abreu et al. 1995) or the Amazonian Lake Batata (Anésio et al. 1997). The higher content of humic substances in this brown-water tropical lagoon may inhibit decomposition (Qualls $\&$ Haines 1990). The concentration of labile DOC (considered here as soluble carbohydrates) in Cabiúnas Lagoon represented less than 7\% of total DOC (Marinho, pers. comm.). Similar dissolved labile carbon and DOC concentrations were observed in temperate eutrophic lakes (Søndergaard et al. 1995). However, the BP observed by these latter authors were higher than in Cabiúnas Lagoon, indicating that only the concentration of labile DOC alone cannot explain the low BP. Apparently, the inter-relationship between temperature and nutrient availability may better explain bacterial production than either of these factors alone (Felip et al. 1996). Nutrient availability did not seem to limit BP in 


\section{TABLE II}

Measurements of water temperature, dissolved oxygen, dissolved organic carbon (DOC) and inorganic (DIC) and nutrients in Cabiúnas Lagoon on September 1998 and in Lake Stechlin and Lake Dagow on February 1997. The values were recorded on the day of sampling.

\begin{tabular}{|c|c|c|c|c|c|c|c|c|c|}
\hline & $\begin{array}{c}\text { Water } \\
\text { temperature } \\
{ }^{\circ} \mathrm{C}\end{array}$ & $\begin{array}{c}\text { Oxygen } \\
\mathrm{mg} \mathrm{l}^{-1}\end{array}$ & $\begin{array}{c}\text { DOC } \\
\mathrm{mg} \mathrm{l}^{-1}\end{array}$ & $\begin{array}{c}\text { DIC } \\
\mathrm{mg} \mathrm{l}^{-1}\end{array}$ & $\begin{array}{l}\text { P-total } \\
\mu \mathrm{g} \mathrm{l}^{-1}\end{array}$ & $\begin{array}{c}\text { SRP } \\
\mu \mathrm{g} \mathrm{l}^{-1}\end{array}$ & $\begin{array}{c}\text { N-total } \\
\mu \mathrm{g} \mathrm{l}^{-1}\end{array}$ & $\begin{array}{c}\mathrm{NO}_{3} \\
\mu \mathrm{g} \mathrm{l}^{-1}\end{array}$ & $\begin{array}{c}\mathrm{NH}_{4} \\
\mu \mathrm{g} \mathrm{l}^{-1}\end{array}$ \\
\hline \multicolumn{10}{|l|}{ Cabiúnas Lagoon } \\
\hline L1 & 26.1 & 5.9 & 11.9 & 1.6 & 9 & 4 & 500 & 5 & 2 \\
\hline $\mathrm{P}^{1}$ & 26.3 & 6.7 & 12.4 & 1.8 & 18 & 2 & 590 & 14 & 14 \\
\hline L2 & 26.8 & 3.5 & 8.6 & 1.5 & 18 & 3 & 590 & 3 & 3 \\
\hline \multicolumn{10}{|l|}{ Lake Stechlin } \\
\hline L1 & 4.0 & 12.1 & 3.9 & 21.7 & 32 & 3 & 298 & 14 & 29 \\
\hline $\mathrm{P}^{1}$ & 3.8 & 12.8 & 3.2 & 21.6 & 15 & 11 & 333 & 22 & 16 \\
\hline L2 & 4.0 & 12.0 & 7.6 & 21.7 & 6 & 9 & 305 & 12 & 6 \\
\hline \multicolumn{10}{|l|}{ Lake Dagow } \\
\hline L1 & 4.8 & 12.9 & 8.62 & 22.0 & 14 & 4 & 782 & 98 & 23 \\
\hline $\mathrm{P}^{1}$ & 4.5 & 13.7 & 8.42 & 22.2 & 15 & 4 & 850 & 78 & 30 \\
\hline L2 & 4.9 & 13.6 & 8.02 & 23.5 & 16 & 4 & 770 & 84 & 24 \\
\hline
\end{tabular}

${ }^{1}$ average of pelagic samples a, b and c. ${ }^{2}$ data from samples collected in August 1998.

Cabiúnas Lagoon (see Table I and II). In this lagoon, the production attributed to picoplankton $(<1 \mu \mathrm{m})$ represents about $35 \%$ of the total planktonic primary production. Picoplankton also exhibit a high rate of carbon excretion, which can support a higher rate of bacterial production (Roland 1998). In addition, the concentration of total phosphorus in the lagoon was similar to that found in Lake Stechlin. Thus, the lagoon has reduced bacterial activity despite high temperature and nutrient availability, suggesting that the microbial community is regulated by other mechanisms.

In the small bay of the tropical lagoon, which is colonized by both emergent and submersed macrophytes, BP was statistically higher and varied from 1 to $33 \mu \mathrm{g} \mathrm{Cl}^{-1} \mathrm{~d}^{-1}$ (Mann-Whitney, $\mathrm{p}<0.05$; Furtado et al. 2000). This result indicates that the littoral zones are sites of greater microbial activity than the principal water body.

In Table III, bacterial biovolume, carbon content and production-biomass ratio (production/ biomass) of water samples from all water bodies are summarized. The lowest bacterial biovolume $\left(0.25 \mu \mathrm{m}^{3}\right)$ was measured in Lake Stechlin, therefore the carbon content $\left(26.04 \mathrm{fg} \mathrm{C}^{-1 l^{-1}}\right)$ and bacterial biomass $\left(26.04 \mu \mathrm{g} \mathrm{C}^{-1}\right)$ were low. The bacterial biovolume was generally higher than observed in most temperate (Tulonen 1993, Tulonen et al. 1996, Hwang \& Heath 1997) and tropical water bodies (Kroer 1994). Bacterial biovolume and corresponding carbon content in Cabiúnas Lagoon and Lake Dagow were similar (Mann-Whitney, $\mathrm{p}<0.05$ ), but the bacterial biovolume and carbon content were significantly different among the stations (KruskalWallis, $\mathrm{p}<0.05$ ). The low bacterial biovolume of cells from Lake Stechlin was responsible for this result suggesting that biovolume was more related to trophic state than activity. Also, the production/ biomass ratio has the same tendency as production, with the lowest $\mathrm{P} / \mathrm{B}$ ratio in Cabiúnas Lagoon (0.03 $\left.\mathrm{d}^{-1}\right)$ and the highest in Lake Dagow $\left(0.78 \mathrm{~d}^{-1}\right)$. Bacterial metabolism was higher in both temperate lakes than in the tropical lagoon.

To ensure that our measurements of BP were not effected by leucine uptake by other micro-organisms and to reduce the effect of isotopic dilu- 


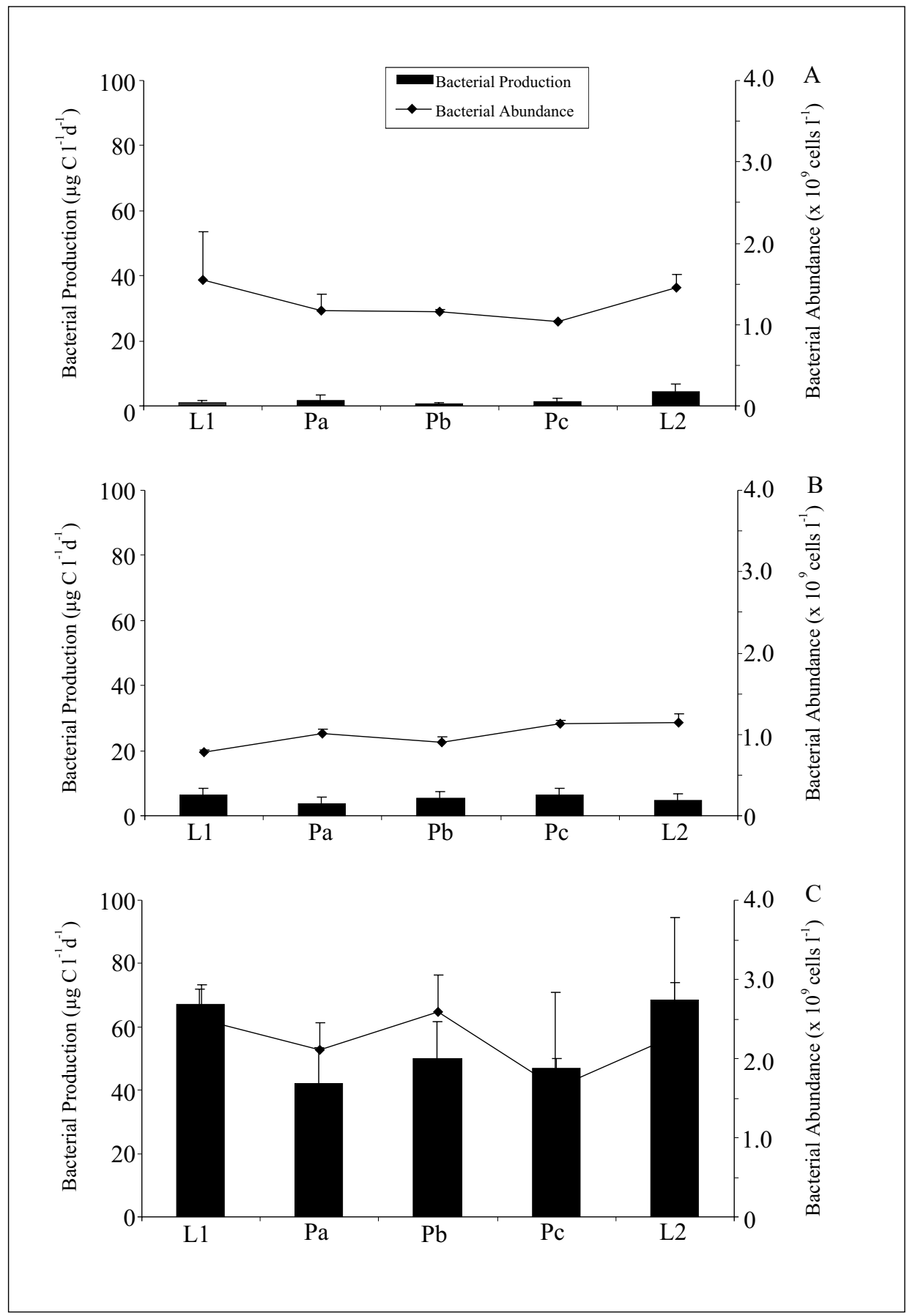

Fig. 1 - Bacterial production and abundance in samples from Cabiúnas Lagoon (A), Lake Stechlin (B) and Lake Dagow (C). L1 - littoral without macrophytes, $\mathrm{Pa}$ - pelagial surface, $\mathrm{Pb}$ - pelagial intermediate, Pc - pelagial bottom and L2 - littoral with macrophytes. Vertical bars represent the average + standard deviation. 


\section{TABLE III}

Bacterial biovolume, carbon content, abundance, biomass, production and $\mathrm{P} / \mathrm{B}$ ratio in water samples from Cabiúnas Lagoon, Lake Stechlin and Lake Dagow. The values represent the average of the three stations (L1, L2 and P) \pm standard deviation.

\begin{tabular}{|c|c|c|c|c|c|c|}
\hline & $\begin{array}{c}\text { Volumen } \\
\mu^{1} \mathrm{~m}^{3}\end{array}$ & $\begin{array}{l}\mathrm{C} \text { content }^{2} \\
\text { fg C cell }\end{array}$ & $\begin{array}{c}\text { Bacterial } \\
\text { abundance } \\
\text { cell } 1^{-1} \times 10^{9}\end{array}$ & $\begin{array}{c}\text { Bacterial } \\
\text { biomass } \\
\mu \mathrm{g} \mathrm{C}^{-1}\end{array}$ & $\begin{array}{c}\text { Bacterial } \\
\text { production } \\
\mu \mathrm{g} \mathrm{C}^{-1} \mathrm{~d}^{-1}\end{array}$ & $\begin{array}{c}\text { P/B ratio } \\
\mathrm{d}^{-1}\end{array}$ \\
\hline Cabiúnas Lagoon & $0.352 \pm 0.209$ & 36.96 & 1.3 & 48.05 & 1.22 & 0.03 \\
\hline Lake Stechlin & $0.248 \pm 0.268$ & 26.04 & 1.0 & 26.04 & 5.30 & 0.2 \\
\hline Lake Dagow & $0.304 \pm 0.171$ & 31.92 & 2.2 & 70.22 & 54.88 & 0.78 \\
\hline
\end{tabular}

1 calculated according to Bratbak (1985). 2 according to Theil-Nielsen and Søndergaard (1998). ${ }^{3}$ Production/ Biomass ratio.

tion, we refined our leucine uptake experiments. We determined the saturation concentration for leucine in water samples from Lake Stechlin. Leucine uptake increased linearly up to $200 \mathrm{nM}$ leucine $\left(\mathrm{r}^{2}=\right.$ 0.9062), following the expression (Fig. 1):

$$
\mathrm{Y}=0.0393 \mathrm{X}
$$

where $\mathrm{Y}$ is the leucine rate uptake $\left(\mathrm{nmol} \mathrm{l}^{-1} \mathrm{~h}^{-1}\right)$ and $\mathrm{X}$ is the concentration of leucine $(\mathrm{nM})$.

In these experiments, isotopic saturation was not reached. Usually, the leucine saturation level is found at a concentration of $10 \mathrm{nM}$ in waters of oligotrophic and marine systems (Kirchman 1993). At this concentration, variation does not occur in the bacterial growth rate and minimizes intracellular isotopic dilution (Simon \& Azam 1989). In contrast, higher leucine concentration (> 200nM) has been recommended for eutrophic environments (van Looij \& Riemann 1993) to reduce both the effect of the intracellular de novo synthesis, and external dilution (Jørgensen 1992). Also, according to Kirchman et al. (1986) the addition of low concentrations of extracellular leucine are enough to inhibit intracellular synthesis. Riemann and Azam (1992), using leucine concentrations up to $100 \mathrm{nM}$, could not find saturation levels in 6 of 7 investigated water samples for several coastal marine and freshwater ecosystems in Denmark.
A concentration of $50 \mathrm{nM}$ leucine was used throughout our experiments. A leucine concentration of $>40 \mathrm{nM}$ is noted to reduce the effect of intracellular dilution by about $90 \%$ in eutrophic lakes (Jørgensen 1992). Additionally, leucine uptake by non-bacterial micro-organisms was minimized in Lake Stechlin samples, when incubated with $50 \mathrm{nM}$. The bacterial production varied from $5.0 \mu \mathrm{g} \mathrm{Cl}^{-1} \mathrm{~d}^{-1}$ in the filtered samples $(<0.8 \mu \mathrm{m})$ to $6.4 \mu \mathrm{g} \mathrm{C}^{-1}$ $\mathrm{d}^{-1}$ in unfiltered samples. The difference was not statistically significant (Mann-Whitney, $\mathrm{p}<0.05$; Fig. 2). The concentration of $50 \mathrm{nM}$ leucine was enough to saturate samples from Cabiúnas Lagoon minimizing isotopic dilution. Farjalla (1998), using a concentration of $10 \mathrm{nM}$ leucine in the same lagoon, observed higher values for bacterial production than measured in this investigation.

\section{CONCLUSIONS}

Despite the lower water temperatures measured on the winter sampling dates, both temperate lakes exhibited higher bacterial production and consequently a higher $\mathrm{P} / \mathrm{B}$ ratio (production/bacterial biomass). Bacterial production was not coupled with abundance, because average bacterial production in Lake Stechlin was about four times higher than in Cabiúnas Lagoon, but bacterial abundance in Lake Stechlin was significantly lower. Highest 


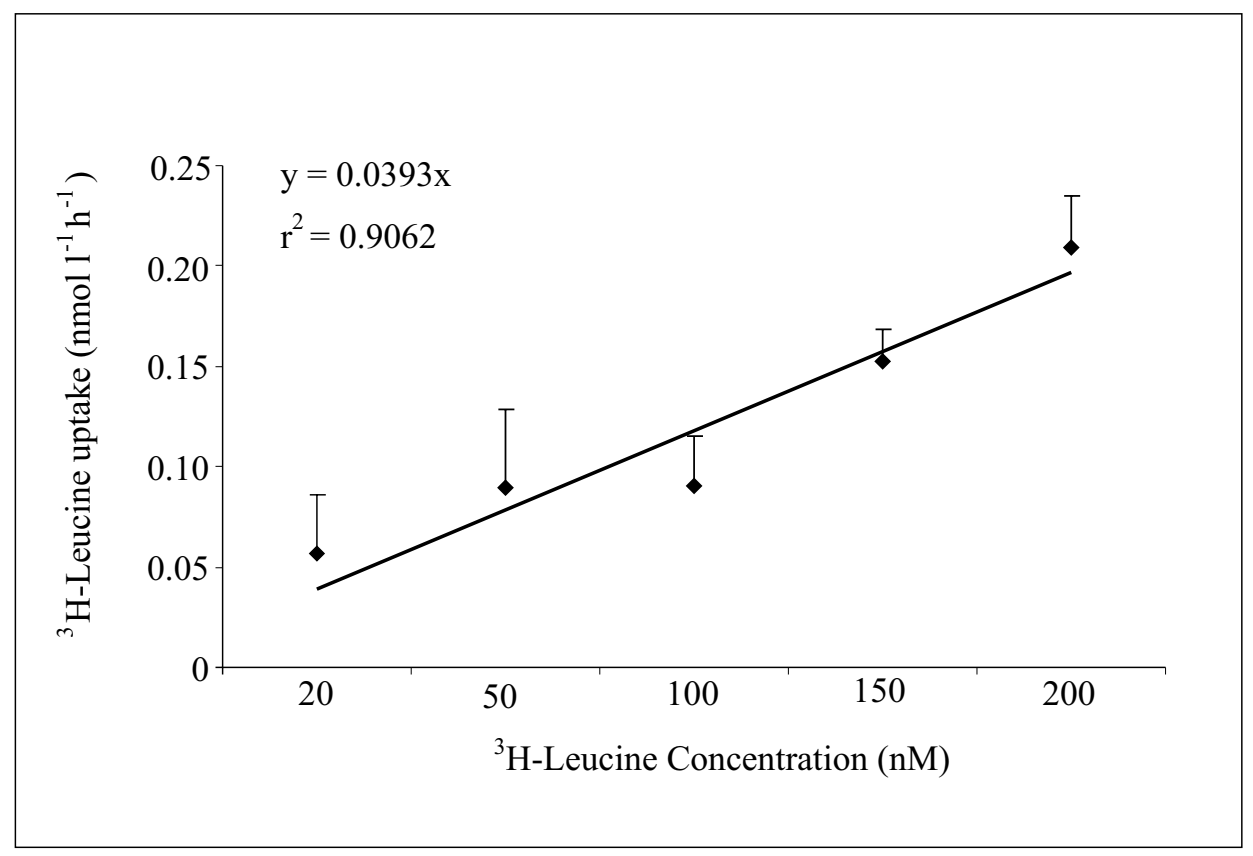

Fig. 2 - Leucine uptake versus leucine concentration in water samples from Lake Stechlin. Vertical bars represent the average $(n=5)+$ standard deviation.

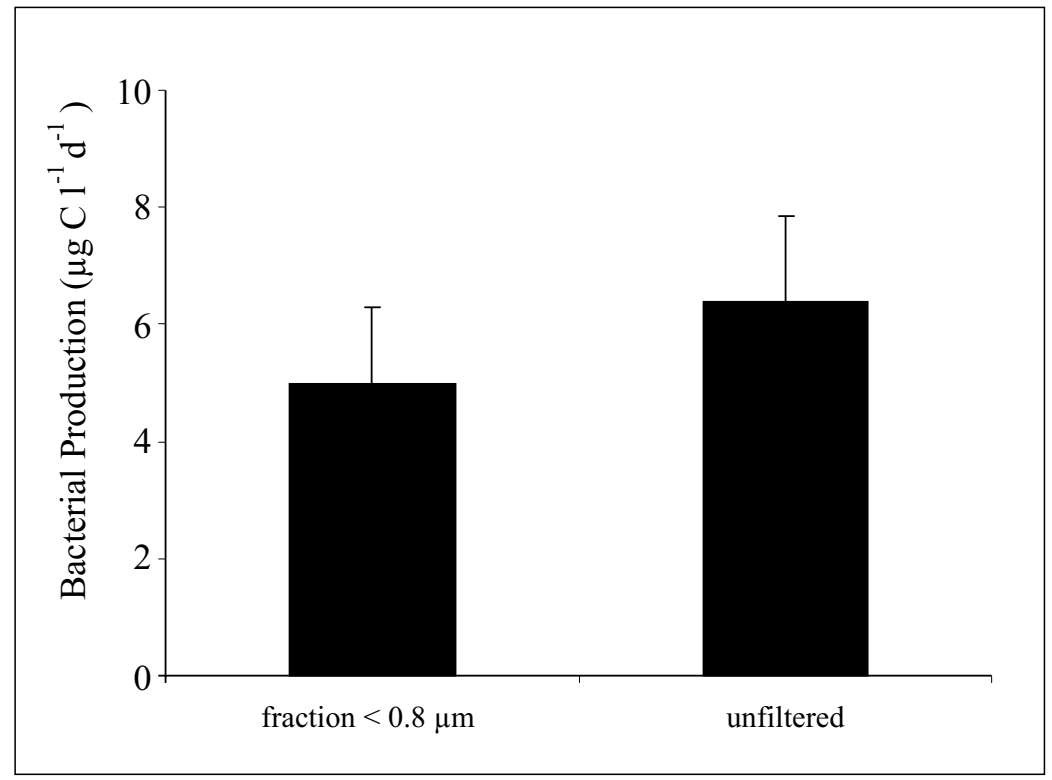

Fig. 3 - Bacterial production in water samples from Lake Stechlin at $<0.8 \mu \mathrm{m}$ and unfiltered sample. Vertical bars represent the average $(n=5)+$ standard deviation. 
bacterial abundance and production were detected in eutrophic Lake Dagow. In this study, trophic state was determined to be most important factor for increasing bacterial production instead of temperature.

The microbial activity in tropical Cabiúnas Lagoon was not regulated by temperature and $\mathrm{N}$ and P-concentrations, indicating that bacterial community is regulated by other more complex interactions, which limited microbial activity in the water column.

Leucine uptake did increase linearly up to 200 $\mathrm{nM}$ indicating that oligotrophic water bodies may show high values of bacterial production and measurements using low concentrations of leucine (10 $\mathrm{nM}$ ) to measure BP may underestimate BP in some systems.

Finally, the leucine uptake by micro-organisms greater than $>0.8 \mu \mathrm{m}$ in size did not influence estimates of BP for oligotrophic Lake Stechlin.

\section{ACKNOWLEDGEMENTS}

We thank the Ökumenisches Studienwerk e.V. for giving a grant to André Luiz dos Santos Furtado including the travel to Brazil, which enabled him to collecting samples in the Cabiúnas Lagoon during his fellowship. We acknowledge R. Koschel (IGB) for providing unpublished limnological data of Lake Stechlin and Lake Dagow, C. Marinho (UFRJ) for carbohydrate data of Lagoon Cabiúnas, H.-D. Babenzien (IGB) for comments on the manuscript, Linde Adams for editorial assistance and Betina K. Suzuki (UFRJ) for the assistance with sampling in Brazil.

\section{RESUMO}

A abundância, biomassa e produção bacterioplanctônica em uma lagoa tropical (lagoa Cabiúnas, Brasil) e em dois lagos temperados (lago Stechlin e lago Dagow, Alemanha) foram comparadas. A abundância e a produção bacteriana foram significativamente diferente entre os três ecossistemas aquáticos. A menor produção bacteriana $(0.8 \mu \mathrm{g} \mathrm{C}$ $\mathrm{I}^{-1} \mathrm{~d}^{-1}$ ) foi observada na lagoa Cabiúnas, apesar da alta temperatura da água e concentração de carbono orgânico dissolvido. A maior abundância $\left(2.6 \times 10^{9}\right.$ células $\left.1^{-1}\right)$ e produção bacterioplanctônica $\left(68.5 \mu \mathrm{g} \mathrm{C}^{-1} \mathrm{~d}^{-1}\right)$ foram medidas no eutrófico lago Dagow. No oligotrófico lago Stechlin, foi observada a menor biomassa bacteriana ( $\left.48.05 \mu \mathrm{g} \mathrm{C}^{-1}\right)$, refletindo o menor volume $\left(0.248 \mu \mathrm{m}^{3}\right)$ e abundância bacteriana. Populações bacterianas nos lagos temperados mostraram maior atividade (razão produção/biomassa) que na lagoa tropical. O efeito da diluição isotópica e a incorporação de leucina por microorganismos não bacterianos foram avaliadas no ecossistema oligotrófico temperado. A absorção de leucina por microorganismos não bacterianos não influenciou significativamente a produção bacteriana.

Palavras-chave: produção bacteriana, incorporação de leucina, lagoa tropical, lagos temperados.

\section{REFERENCES}

Abreu PC, Graneli HW \& Odebrecht C. 1995. Produção fitoplanctônica e bacteriana na região de pluma estuarina da Lagoa dos Patos - RS, Brasil. Atlântica 17: $35-52$.

Anésio AM, Abreu, PC \& Esteves FA. 1997. Influence of the hydrological cycle on the bacterioplankton of an impacted clear water Amazonian Lake. Microb Ecol. 34: 66-73.

Araújo DSD \& Henriques RP. 1984. Análise florística das restingas do Estado do Rio de Janeiro. In: Lacerda LD et al. (Ed.); Restingas: origem, estrutura e processos. Niterói: CEUFF, p. 159-193.

BAbEnZIEN H-D \& BABEnZIEn C. 1985. Microbial activities at Lake Stechlin. In: CASPER SJ (Ed.); Lake Stechlin. A temperate oligotrophic lake. Dordrecht, The Netherlands: Dr. WJ Publishers, p. 347-373.

Bratbak G. 1985. Bacterial biovolume and biomass estimations. Appl Environ Microbiol 49: 1488-1493.

CASPER SJ. 1985. Lake Stechlin. A temperate oligotrophic lake. Dordrecht, The Netherlands: Dr. WJ Publishers, p. 553.

Chrzanowski TH, Kyle M, Elser JJ \& Sterner RW. 1996. Element ratios and growth dynamics of bacteria in an oligotrophic Canadian shield lake. Aquat 
Microb Ecol 11: 119-125.

FARJALla VF. 1998. Nutrientes limitantes ao crescimento do bacterioplâncton nas lagoas Carapebus, Comprida, Cabiúnas e Iodada. In: Esteves FA (Ed.); Ecologia das lagoas costeiras do Parque Nacional da Restinga de Jurubatiba e do Município de Macaé $(R J)$. Rio de Janeiro: UFRJ/NUPEM, p. 147-157.

Felip M, Pace ML \& Cole JJ. 1996. Regulation of planktonic bacterial growth rates: the effects of temperature and resources. Microb Ecol 31: 15-28.

Furtado ALS, Casper P \& Esteves FA. 2000. Heterotrophic bacterial production in a Brazilian humic coastal lagoon. Verh Internat Verein Limnol, (in press).

Golterman HL, Clymi RS \& Ohmstad AM. 1978. Methods for physical and chemical analysis of fresh water. Oxford: Blackwell Scientific Publ., p. 214.

Gomes LC \& Agostinho AA. 1997. Influence of the flooding regime on the nutritional state and juvenile recruitment of the curimba, Prochilodus scrofa, Steindachner, in upper Paraná River, Brazil. Fish Manag Ecol 4: 263-274.

Hecky RE, Campbell P \& Hendzel LL. 1993. The stoichiometry of carbon, nitrogen and phosphorus in particulate matter of lakes and oceans. Limnol Oceanogr 38: $709-724$.

Hwang S-J \& Heath RT. 1997. Bacterial productivity and prostistan bacterivory in coastal and offshore communities of Lake Erie. Can J Fish Aquat Sci 54: 788-799.

JøRGENSEN NOG. 1992. Incorporation of $\left[{ }^{3} \mathrm{H}\right]$ leucine and $\left[{ }^{3} \mathrm{H}\right]$ valine into protein of freshwater bacteria: uptake kinetics and intracellular isotope dilution. Appl Environ Microbiol 58: 3638-3646.

JunK WJ \& FurCH K. 1993. A general review of tropical South American floodplains. Wetlands Ecol Manag 2: 231-238.

KAMJUnKe N \& JÄHNichen S. 2000. Leucine incorporation by Microcystis aeruginosa. Limnol Oceanogr 45: 741-743.

KePNER RLJR \& PRATt JR. 1994. Use of fluorochromes for direct enumeration of total bacteria in environ- mental samples: past and present. Microbiol Rev 58: 603-6175.

KiRCHMAN DL. 1993. Leucine incorporation as a measure of biomass production by heterotrophic bacteria. In: Kemp PF et al. (Eds.); Handbook of methods in aquatic microbial ecology. Florida, Boca Raton: Lewis Publishers, p. 509-512.

Kirchman DL, Newell SY \& Hodson RE. 1986. Incorporation versus biosynthesis of leucine: implications for measuring rates of protein synthesis and biomass production by bacteria in marine systems. Mar Ecol Prog Ser 32: 47-59.

Kroer N. 1994. Relationships between biovolume and carbon and nitrogen content of bacterioplankton. FEMS Microbiol Ecol 13: 217-224.

LAMPERT W \& SOMmer U. 1993. Limnoökologie. Stuttgart: Georg Thieme Verlag, p. 440.

Lindell M \& EDLing H. 1996. Influence of light on bacterioplankton in a tropical lake. Hydrobiologia 323: $67-73$.

OSKAM G \& VAN Genderen J. 1996. Eutrophication and development of algae in surface water - a threat for the future? Water Supply 14: 415-424.

Panosso RF, Attayde JL \& Muehe D. 1998. Morfometria das lagoas Imboassica, Cabiúnas, Comprida e Carapebus: implicações para seu funcionamento e manejo. In: Esteves FA (Ed.); Ecologia das lagoas costeiras do Parque Nacional da Restinga de Jurubatiba e do Município de Macaé (RJ). Rio de Janeiro: UFRJ/NUPEM, p. 91-108.

PERrin P. 1984. Evolução da costa fluminense entre as Pontas de Itacoatiara e Negra: preenchimentos e restingas. In: Lacerda LD et al. (Eds.); Restingas: origem, estrutura e processos. Niterói: CEUFF, p. $65-74$

Petrucio MM. 1998. Caracterização das lagoas Imboassica, Cabiúnas, Comprida e Carapebus a partir da temperatura, salinidade, condutividade, alcalinidade, oxigênio dissolvido, $\mathrm{pH}$, transparência e material em suspensão. In: Esteves FA (Ed.); Ecologia das lagoas costeiras do Parque Nacional da Restinga de Jurubatiba e do Município de Macaé(RJ). Rio de Janeiro: UFRJ/NUPEM, p. 109-122. 
Qualls RG \& HaInes BL. 1990. The influence of humic substances on the aerobic decomposition of submerged leaf litter. Hydrobiologia 206: 133-138.

Reche I, CARrilo P \& Pizarro-Cruz L. 1997. Influence of metazooplankton on interactions of bacteria and phytoplankton in an oligotrophic lake. J. Plankton Res 19: 631-646.

Riemann B \& Azam F. 1992. Measurements of bacterial protein synthesis in aquatic environments by means of leucine incorporation. Mar Microb Food Webs 6: 91-105.

Roland F. 1998. Produção fitoplantônica em diferentes classes de tamanho nas Lagoas Imboassica e Cabiúnas. In: Esteves FA (Ed.); Ecologia das lagoas costeiras do Parque Nacional da Restinga de Jurubatiba e do Município de Macaé(RJ). Rio de Janeiro: UFRJ/NUPEM, p. 159-175.

Simon M \& Azam F. 1989. Protein content and protein synthesis rates of planktonic marine bacteria. Mar Ecol Prog Ser 51: 201-213.

Smith DC \& Azam F. 1992. A simple, economical method for measuring bacterial protein synthesis rates in seawater using ${ }^{3} \mathrm{H}$-leucine. Mar Microb Food Webs 6: 107-114.
SøndergaArd M, Hansen B \& Markager S. 1995. Dynamics of dissolved organic carbon lability in a eutrophic lake. Limnol Oceanogr 40: 46-54.

Theil-Nielsen J \& SøndergaArd M. 1998. Bacterial carbon biomass calculated from biovolumes. Arch Hydrobiol 141: 195-207.

Tulonen T. 1993. Bacterial production in a mesohumic lake estimated from $\left[{ }^{14} \mathrm{C}\right]$ leucine incorporation rate. Microb Ecol 26: 201-217.

Tulonen T, Kankanla P \& Ojala A. 1996. Production of bacteria in the littoral zone of two experimental mesohumic ponds. Arch Hydrobiol Spec Issues Advanc Limnol 48: 217-225.

VAN LoOIJ A \& Riemann B. 1993. Measurements of bacterial production in coastal marine environments using leucine: application of a kinetic approach to correct for isotope dilution. Mar Ecol Prog Ser 102: 97-104.

White PA, KalfF J, Rasmussen JB \& Gasol JM. 1991. The effect of temperature and algal biomass on bacterial production and specific growth rate in freshwater and marine habitats. Microb Ecol 21: 99-118. 